\title{
Oceanography
}

CITATION

Kappel, E.S. 2016. In memory of Tom Garrison. Oceanography 29(4):5,

http://dx.doi.org/10.5670/oceanog.2016.89.

DOI

http://dx.doi.org/10.5670/oceanog.2016.89

COPYRIGHT

This article has been published in Oceanography, Volume 29, Number 4, a quarterly journal of The Oceanography Society. Copyright 2016 by The Oceanography Society. All rights reserved.

USAGE

Permission is granted to copy this article for use in teaching and research.

Republication, systematic reproduction, or collective redistribution of any portion of this article by photocopy machine, reposting, or other means is permitted only with the approval of The Oceanography Society. Send all correspondence to: info@tos.org or The Oceanography Society, PO Box 1931, Rockville, MD 20849-1931, USA. 


\section{In Memory of Tom Garrison}

Tom Garrison, beloved professor of marine science at Orange Coast College, author of the widely used introductory textbook Essentials of Oceanography, and important to us, an Oceanography magazine education columnist for a decade, passed away in February after a battle with lymphoma. Through his 20 columns, all of which are available at https://tos.org/classroom, Tom generously shared with us his love of teaching, especially for his big introductory oceanography class for nonmajors. He wrote about topics such as how to plan your course curriculum, how to deal with "distracted" students, how to grab students' attention, and even why words are important (a column any editor would love) - all delivered with humor and grace. Tom admonished those who lamented students' inattention and lack of focus in lectures by saying "Get a grip!" and offered these inspiring words:

For a generation of students who don't know the causes of the seasons, who think all dolphins are cuddly and intelligent, who may believe Earth is about 10,000 years old, and who sometimes view organic evolution with grave suspicion, we may offer a last chance to invite critical thought.

Tom was already an Oceanography education columnist when I came on board as editor, but it's evident why he was invited to regularly contribute to the magazine. In his clear, engaging prose, he made us think about the larger role teachers of college-level introductory oceanography courses must play in getting students to question what they read on their favorite Internet sites or glean from radio and TV. In his March 2006 column "Boiling for Science," Tom wrote:

Our world is based in critical thought, and we need to demonstrate these ideas in our lab courses from Day One. Students are usually confident there is a Right Answer to every question. When presented with a high-profile public spat (as between "intelligent design" and organic evolution, or whether vitamin C cures colds, or whether global warming is happening), students tend to pick the answer represented by the person or group they like most and doggedly stick with it. They almost never question The Truth about anything of concern.

Most of the rest of that column takes readers step by step through his honors oceanography lab exercise that leads students on the road to discovery that there is "no Absolute Truth in Science," first by having them make their own breakthrough about calibration. The column is a fun read, and provides food for thought, even if you don't use this particular lab in your own classroom.

There is so much more teaching wisdom that Tom shared with readers of Oceanography than could fit here. Despite an early column or two referring to "slides" and "overheads," Tom's education columns are timeless, and I encourage you to go back and read them. It is fitting to conclude this tribute to Tom with a quote from the last paragraph of his very first Oceanography column, published in 2003 (https://doi.org/10.5670/oceanog.2003.56):

In a future column I'll list a few specific ideas that may be of interest to the beginning general instructor. For now, remember that lifelong learning is the truest joy, a pleasure that does not diminish with age, a source of wisdom and calm. Our students can learn much about patience, hope, and optimism from the ocean. We can learn much about the world-and about ourselves-by looking for the oceanic connections among things. There is much good in the world. Go and add to it.

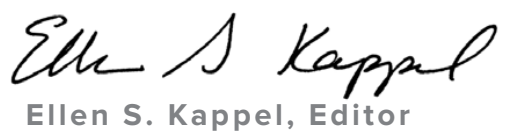

